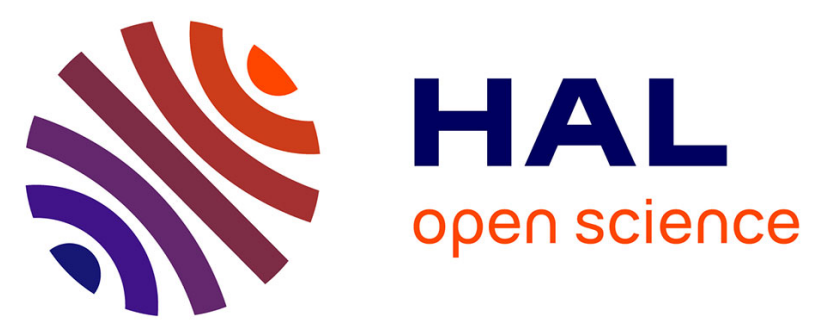

\title{
Structural and Infrastructural Practices as Elements of Content Operations Strategy. The Effect on Firm Competitiveness
}

Eloisa Diaz-Garrido, Maria Luz Martin-Peña, Fernando Garcia-Muina

\section{- To cite this version:}

Eloisa Diaz-Garrido, Maria Luz Martin-Peña, Fernando Garcia-Muina. Structural and Infrastructural Practices as Elements of Content Operations Strategy. The Effect on Firm Competitiveness. International Journal of Production Research, 2007, 45 (09), pp.2119-2140. 10.1080/00207540600735480 . hal-00512913

\section{HAL Id: hal-00512913 \\ https://hal.science/hal-00512913}

Submitted on 1 Sep 2010

HAL is a multi-disciplinary open access archive for the deposit and dissemination of scientific research documents, whether they are published or not. The documents may come from teaching and research institutions in France or abroad, or from public or private research centers.
L'archive ouverte pluridisciplinaire HAL, est destinée au dépôt et à la diffusion de documents scientifiques de niveau recherche, publiés ou non, émanant des établissements d'enseignement et de recherche français ou étrangers, des laboratoires publics ou privés. 


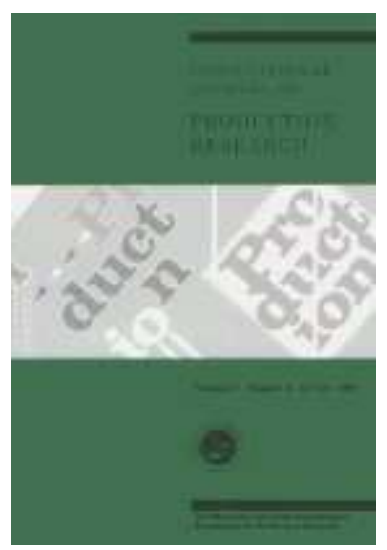

\section{Structural and Infrastructural Practices as Elements of Content Operations Strategy. The Effect on Firm Competitiveness}

\begin{tabular}{|c|c|}
\hline Journal: & International Journal of Production Research \\
\hline Manuscript ID: & TPRS-2005-IJPR-0531.R1 \\
\hline Manuscript Type: & Original Manuscript \\
\hline $\begin{array}{r}\text { Date Submitted by the } \\
\text { Author: }\end{array}$ & 30-Mar-2006 \\
\hline Complete List of Authors: & $\begin{array}{l}\text { Diaz-Garrido, Eloisa; Rey Juan Carlos University, Business and } \\
\text { Organisation } \\
\text { Martin-Peña, Maria Luz; Rey Juan Carlos University, Business and } \\
\text { Organisation } \\
\text { Garcia-Muina, Fernando; Rey Juan CArlos University, Business and } \\
\text { Organisation }\end{array}$ \\
\hline Keywords: & OPERATIONS STRATEGY, PRODUCTIVITY \\
\hline Keywords (user): & MANUFACTURING PRACTICES, COMPETITIVENESS \\
\hline
\end{tabular}

\section{s ScholarONE" \\ Manuscript Central}




\title{
Structural and Infrastructural Practices as Elements of Content Operations Strategy. The Effect on Firm Competitiveness
}

\author{
ELOÍSA DÍAZ-GARRIDO* \\ MARÍA LUZ MARTÍN-PEÑA \\ FERNANDO GARCÍA-MUIÑA
}

\author{
Rey Juan Carlos University \\ Facultad de CC Jurídicas y Sociales \\ Departamento de Economía de la Empresa (ADO) \\ Paseo de los Artilleros s $\mathrm{n}^{\circ}$, 28032, Madrid, Spain \\ Tel: +34 914887790/91, Fax: +34914887780 \\ *Corresponding author. Email: eloisa.diaz@urjc.es
}




\title{
Structural and infrastructural practices as elements of content operations strategy. The effect on firm competitiveness
}

\begin{abstract}
Some extant theoretical studies and different empirical results have demonstrated that firms' behaviour explains several notable competitiveness microeconomic foundations, based on a wide bundle of elements. Firms can directly control most of these elements; in this paper, we will focus on those related to operations management. So, products, processes, technology, equipments or quality control systems will centre our attention. These ones and some additional elements constitute decisions within operations management area that must be included in the content of operations strategy. Operations strategy can be conceptualized as a set of decisions or practices with regard to structure and infrastructure variables. On the one hand, these strategic decisions influence firm's abilities to successfully reach some competitive priorities such as, cost, quality, delivery, and flexibility, and, on the other hand, to obtain the expected performance. This research analyses which are the main structural and infrastructural practices that constitute operations strategies in manufacturing companies, and test the effect of these decisions on some firm competitiveness indicators.
\end{abstract}

Keywords: Operations strategy, Manufacturing practices, Competitiveness, Productivity

\section{Introduction}

In current contexts, firms' behaviour establishes some of the most important microeconomic foundations for their competitiveness, based on a wide bundle of elements, as markets or operations and delivery systems, among others (Bradford, 1994). The notable complexity degree of all these factors forces firms to define and 
develop some innovative strategies, if they want to sustain their successful competitive position.

Most of these elements can directly be controlled by firms; in this paper we will focus on those related to operations management. So, products, processes, technology, equipments or quality control systems will centre our attention. Following previous literature, we can derive that all of them can influence firms' competitiveness ('e.g.' profitability or productivity). In this new competitive landscape, value creation demands a complete redefinition of many traditional operations systems and strategies.

Taking into account all these arguments, we state that operations management can meaningfully contribute to better results (Skinner, 1969; Buffa, 1984; Swamidass, 1986; Hayes et al., 1988; Hill, 1989). In this situation, the explicit definition of manufacturing objectives as well as the development and implementation of different specific policies and practices, oriented to successfully achieve these objectives, will be necessary. This issue has been supported by several authors, as Hayes \& Schemenner (1978), Fine \& Hax (1985), Schroeder et al. (1986), Cleveland et al. (1989), Roth (1989); Leong et al. (1990), Boyer (1998), Marucheck et al. (1990).

Operations management can be considered as an operational instrument to gain those competitive advantages defined at strategic business unit level (Hayes \& Wheelwright, 1984; Corbett \& Van Wassenhove, 1993). Therefore, operations management must be integrated into the entire firm strategic process. Then, operations strategy and competitive strategy must be congruent and strongly linked (Anderson et al., 1989; Wheelwright \& Hayes, 1985; Wheelwright, 1984).

Within the strategic management literature, a growing stream of thought argues that firms' resources and capabilities (Prahalad \& Hamel, 1990; Teece \& Pisano, 1994) 
explain the most important performance differences. Integrating operations management within the strategic process, we support that firms' success depends on the efficient exploitation of manufacturing resources and capabilities, by the manufacturing best practices (Hayes \& Wheelwright, 1984; Schonberger, 1986; Giffi et al., 1990).

The arguments presented here are directly based on the three operations strategy paradigms proposed by Voss (1995). From his point of view, none of them can solely explain an effective development of operations strategy; nevertheless, their joint treatment contains all the necessary elements to do that.

One of these elements is manufacturing practices. Within the definition of the operations strategy, content and context aspects must be explicitly considered. Content dimension includes strategic decisions in structure (technology process, plant capacity and location, vertical integration degree) and in infrastructure (quality management systems, planning and control systems, inventory management, work force or organisational design) that influences firms' abilities to successfully obtain their competitive priorities (cost, quality, flexibility, delivery and service). From the operations strategy concept, these decisions must capture competitive priorities defined at strategic business unit level.

There is a growing interest in the study of the relationship between operations strategy and competitive advantage -most literature focuses on the relationship between competitive priorities and performance- (Cleveland et al., 1989; Vickery, 1991; Kim \& Arnold, 1992; Safizadeh et al., 2000). By contrast, the effect of structural and infrastructural decisions of operations strategy on performance has received less attention (Swink et al., 2005; Narasimhan et al., 2005). To surpass this shortcoming we develop the present paper. 
Based on all these arguments, in this paper we analyze two complementary issues: a) which are the main decisions and practices that constitute operations strategies in manufacturing companies, and b) their effect on firms' competitiveness, in terms of productivity. The previously mentioned decisions are proposed to be multi-dimensional concepts. We expect that current research will help researchers to better understand the scope of policies and practices associated with operations strategy. Furthermore, we offer a validated instrument to measure the structural and infrastructural decisions, and provide some additional empirical evidence concerning the effect of these decisions on companies' competitiveness.

The rest of the paper is organized as follows. Firstly, we develop a complete theoretical framework about the practices to be included within operations strategy; the treatment of each one includes a complete definition as well as the necessary arguments to justify its relevance for firms. Secondly, we offer some operational measures for the included constructs. To identify different kinds of structural and infrastructural decisions taken by Spanish manufacturing firms, we develop an exploratory factor analysis; in addition, to analyse the relationship between these structural and infrastructural operations decisions and firms' competitiveness we use a regression equation model. Finally, some conclusions and implications for future research are presented too.

\section{Theoretical background}

Voss (1995) identifies three 'paradigms` or theoretical frameworks dealing with decisions and content operations strategy, taking into account the reference to the Skinner's seminal work (1969). The first one considers operations as an instrument to compete in markets, the second one is focused on both internal and external operational 
consistency and, the third one focuses on the positive effect of 'best practices`on firm's operations behaviour.

The first framework is the simplest one, as it considers manufacturing as a mere competitive function. In other words, any firm may have or control different operations capabilities that can be used as strategic assets that must be defined in coherence with success key market factors, global and marketing strategies as well as market demand (Skinner, 1969, 1985; Wheelwright \& Hayes, 1985; Slack \& Lewis, 2002).

Nevertheless, several papers dealing with manufacturing activities have considered that operations decisions should actively influence global strategy and not only react to it (Hayes \& Wheelwright, 1984; Buffa, 1984; Hill, 1989). In the same stream of thought, Platts \& Gregory (1992) supported the relevance of operations strategy and evaluated it in terms of firms' objectives; from this argument, they considered that firm capabilities are the base for developing innovative operations strategies.

In addition, other models define and propose measures for operations capabilities. In this sense, Noble (1995) suggests that operations capabilities must be developed consecutively in a path-dependent sense, in order to be mutually reinforced. His findings show that more competitive plants are those that compete on the basis of their non-imitable and non-substitutable operations capabilities.

The identification of some internal success key factors related to operations management has been another research area that has received great attention the in literature. A notable contribution is Hill's proposal, who argues that markets where firms act must be analyzed in terms of those criteria that could explain a competitive advantage position, as price, delivery, quality, product design, and product variety (Miller \& Roth, 1994; Platts \& Gregory, 1992). 
The Voss' (1995) second paradigm is the one related to manufacturing decisions considering content operations strategy from an integral consistency -internal: among all manufacturing decisions, capabilities and competitive priorities; and external: among all manufacturing decisions, and competitive strategy- point of view. Skinner (1969) identified that key content operations decision areas were those related to layout and equipment design, production planning and control systems, work force, product design and organisation. Hayes \& Wheelwright (1984) introduced new elements, but Hill (1993) focused only on two operations decisions: process and operations infrastructures, or in other words, structural and infrastructural operations decisions, as Heineke stated (1995: 257). Such decisions were studied from a contingent approach, as they are influenced by the context in which firm develop their production activities as well as the competitive strategy (Acur et al., 2003).

The third theoretical framework refers to implementing operations 'best practices', as their continuous development moves firms to gain an advantageous position. Best practices refers to several techniques, as material planning requirement (MRP), Flexible Manufacturing Systems (FMS), Just in Time production (JIT), lean production, Total Quality Management (TQM), concurrent engineering, and the like.

From implementing these operations best practices emerges a sort of production systems, named 'World Class Manufacturing', (Hayes y Wheelwright, 1984; Schonberger 1986). This concept was introduced by Hayes y Wheelwright (1984) to describe those capabilities developed by Japanese and Germany firms to compete in foreign markets.

From this perspective, Voss' three paradigms are related to the content of operations strategy. But none of them can explain an effective development of operations strategy 
solely; nevertheless, their joint treatment contains all the necessary elements to do that. The research agenda presented in this paper will cover these three paradigms with particular emphasis on the strategic decisions or practices linked to the content of operations strategy approach, considering which these decisions are and how they affect organisation competitiveness.

\subsection{Defining operations practices}

Firms' competitive priorities and different areas of decision delimit the content of operations strategy. Both concepts are strongly interrelated as operations decisions and competitive priorities must be congruent. The fit between these variables and the necessary investments in operations structure and infrastructure, may justify the role of operations area as a source of sustainable competitive advantage, as it is showed in Anderson et al. (1989), Buffa (1984); Cohen \& Lee (1985), Hayes \& Schmenner (1978), Hayes \& Wheelwright (1984), Roth (1989), Schroeder et al. (1986), Skinner (1969), Stobaugh \& Telesio (1983), Swamidass \& Newell (1987), Voss (1995), Acur et al. (2003).

There is no consensus among scholars about how to establish the areas of decisions that must be included in the operations function. Following Schroeder (1981), these areas influence the way competitive priorities will be reached. Some authors directly identify operations decisions with firm strategy (Hayes y Wheelwright, 1984) or with operations objectives (Swamidass y Newell, 1987). If we integrate the arguments presented up to here, we can define them as the bundle of practices that constitutes the entire operations strategy and contributes to get operations competitive priorities and general firm's objectives. Therefore, firms are only well positioned when competitive priorities are 
strongly supported by operations decisions (Hill, 1993; Kim \& Arnold, 1996; Boyer \& McDermott, 1999; Smith \& Reece, 1999; Acur et al., 2003; Christiansen, et al., 2003;

\section{Swink et al., 2005).}

There are several studies trying to delimit and establish which areas of operations strategy decisions should be included (table 1). The conceptual framework can be organised around two general categories: structural decisions and infrastructural ones. This distinction was initially proposed by Hayes \& Wheelwright (1984), and supported by some others some years later ('e.g.' Hayes et al.; 1988, Hill, 1993; Heineke, 1995).

[Insert table 1 about here]

Almost all structural decisions have several remarkable strategic implications, they require substantial financial investments, and have great effects on physical assets. They have long-term impact and they are not easily reversible, once they have been taken.

Decisions that are more common are those related to some structural practices:

- Manufacturing process technology. Regarding to this variable, firms may produce either high volumes of homogeneous and undifferentiated products, or low volumes of differentiated ones, specific to customers' preferences by using general equipment or manufacturing machines (Hayes \& Wheelwright, 1984). Innovative information technologies let firms develop and exploit new automation manufacturing technologies that give these firms with more flexible and efficient solutions for material requirement planning or operations engineering (Meredith, 1987; Boyer et al., 1996; Narasimhan et al., 2005).

- Vertical integration degree. Managers have to decide which raw materials or components are necessary to be internally developed and which ones must be externally bought. Many firms consider that vertical integration is a useful 
choice to get economies of scale. Nevertheless, only those activities that are core are included in the value chain of firms (Ferdows et al. 1986; Ward et al. 1988; Kim \& Arnold, 1996). In this sense, practices such as supplier partnering, joint programs with suppliers, and integration of information systems with suplliers are very important (Narasimhan et al., 2005).

- Facilities: size, capacity and location. Facilities operations decisions refer to size, capacity and plant location. With respect to factory size, managers may prefer large facilities or, by contrast, small ones. Large size plants may let firms to get a great amount of low-cost components and products, in addition to economies of scale. On the contrary, small plants are more appropriate to flexible organisations. The adoption innovative manufacturing information technology may get both manufacturing competitive priorities consecutively: cost and flexibility. Then, taking into account operations objectives and firm global objectives, production managers must decide which plant size will be more adequate (Ward et al. 1988; Roth \& Miller, 1990).

Factory capacity refers to the level and variety of manufacturing output. Managers must decide if they prefer a great variety of products for different segments or, by contrast, a great level of homogeneous products for only a few segments (Ward et al., 1988; Horte et al., 1991; De Meyer, 1992).

Finally, plant location is of great interest to operations managers; firm may prefer to increase either their existent plants or to build other new ones in different places. Location may depend on a great amount of factors as location of raw materials, location of markets, availability of transportation and communication systems, qualification of work force, and the like. Nowadays, 
globalization is affecting firms' location decisions, as they must be competitive within a unique market (De Meyer, 1992; Kim \& Arnold, 1996).

With respect to the infrastructural decisions or practices, we can derive that they have operatives effects on current costs and have short run effects on firm performance because do not require large capital investments. They comprise just operational practices and decisions that correspond to operations managers exclusively. These decisions may become considered as strategic or tactic choices because refer to the systems, policies, practices, procedures and organisation which support the manufacturing processes and enable them to perform their function. Their accumulative influences can be as difficult and costly to change, as the structural ones are (Wheelwright, 1984). Among infrastructure, decisions or practices we remark the following ones:

- Production and inventory planning and control systems. Within this concept are included two main decisions. Firstly, to evaluate either centralization or decentralization to middle managers are preferred decision systems; secondly, to elect between two alternatives operations options: the push system and the pull one. On the one hand, push system, as Material Requirement Planning, takes as basic reference expected sales. On the other hand, pull system, as Just in Time, uses real demand; in other words, nothing is produced if it is no demanded. This implies that planning is short-run developed, reducing inventories of raw materials, developing products, and final products (Ferdows et al., 1996; Tunälv, 1992; Narasimhan et al., 2005).

- Organisational structure and design. Authority and responsibility systems embedded in organisational structure are essential to successfully support the 
remaining operations decisions. Organisational structures can be based on either normalisation or autonomy. Normalised structures are those integrated by nonautonomous employees that strictly follow rules and procedures previously established. This kind of organisations presents a great amount of hierarchical levels, considering operations systems as a mere cost centre based on formal authority. On the contrary, the organic structures are those where experienced employees can take their own decisions to solve different operations contingencies. This second point of view considers plants as a profit centre (Boyer, 1998; Horte et al. 1991; Boyer \& McDermott, 1999).

- Work force management. Comprises several areas as recruitment, selection, and formation processes, person to job assignation, pay systems and incentive policies or job analysis processes, among others. The most important challenge rests on the definition of that human resource policy that aligns firm objectives and employees' expectations (De Meyer, 1992; Ward et al. 1994; Boyer, 1998).

- Quality management. This variable can be defined from two alternative points of view. On the one had, quality management can be defined a simple quality control process oriented to reduce the number of defect final products. Therefore, it is just an inspection process and quality managers have a minor responsibility. On the other hand, quality management can be considered as an entire operations philosophy trying to erode any source of defects. From this second perspective, it is remarked the role of continuous improvement in cost reducing and productivity (Ward et al. 1988; Horte et al. 1991; Kim \& Arnold, 1996). 
Nowadays, the growing interest in environmental protection implies the adoption of some practices and operations decisions as the development of some environmental management systems or the ISO 14001 certification (Gupta, 1995; Shrivastava, 1995). In short, managers have to take all these decisions with respect to the previously mentioned categories of variables. Furthermore, there are many different choices for any manufacturing decision that can strongly influence firm and competitive strategy of firms (Wheelwright, 1984).

Summing up, in Table 2 we present the measures of structural and infrastructural operations decisions that has been used as reference for our empirical study. Our proposal derived from previous relevant theoretical and empirical papers dealing with this field.

\section{[Insert Table 2 about here]}

\section{Empirical analysis}

\subsection{Sources of information}

Having reviewed the theoretical bases of the manufacturing practices and decisions as elements of content operations strategy, the objectives pursued and methodology used in this work based on the main Spanish industrial companies are reported as follows.

We built our own database for the empirical study, using information contained in the database of 50,000 Main Spanish Companies, edited by Dun and Bradstreet (2002 edition). Specifically, we took a sample of firms, guided by the following two criteria:

a) Industrial firms included (according to the Spanish industry classification system, CNAE) in the groups DJ (Metallurgy \& Manufacture of Metallic Products), DK 
(Manufacture of Machinery and Mechanical Equipment), DL (Electrical, Electronic and Optical Materials and Equipment), and DM (Manufacture of Transport Materials).

b) Firms with more than 50 employees.

The total number of firms contained in the Dun and Bradstreet database complying with the previous criteria, and consequently participating in the study, was 1820 companies. The unit of analysis used was the production unit or manufacturing business unit (Roth \& Miller, 1990; Kim \& Arnold, 1992, 1996; Tunälv, 1992; Avella et al., 1999; Kathuria, 2000). The manufacturing unit corresponds to a firm (for medium-sized firms), department, division, plant or factory (in the case of large firms), each one of which has its own manufacturing strategy, for which the operations managers will adopt different structural and infrastructural decisions.

\subsection{Data gathering}

As primary source of information, we used a questionnaire that we sent by post to each firm's operations manager from the selected sample (in absence of such manager we sent de questionnaire to the CEO). Before sending the definitive version, we carried out a pre-test to control its validity. This involved personal interviews with both academics and operations management specialists from five companies from the sample.

The definitive questionnaire comprises a series of questions designed, on the one hand, to collect basic data about the respondent, their firm, and the type of activity, product and production process, and, on the other hand, to evaluate the decisions related to manufacturing structure and infrastructure. The questionnaire did not include any questions asking for numerical data concerning the results, sales turnover, total assets ${ }^{1}$,

\footnotetext{
${ }^{1}$ We used secondary sources of information to obtain these data, such as the database of 50,000 Main Spanish Companies (from Dun and Bradstreet), and the DICODI directory of Spanish companies.
} 
or similar. This was to facilitate response and avoid a negative predisposition on the part of the respondents.

The total number of valid questionnaires received during the period of data collection was 353 , what means a response rate about the $19.53 \%$.

\subsection{Measures of variables}

To operationalize all the manufacturing policies and practices several items were defined, as can be seen in Table 3. We have considered 34 possible manufacturing practices, which fit into at least one kind of manufacturing decisions identified in the literature.

Exactly these scales are strongly supported in previous operations empirical research. They are similar to those included in the International Survey on the Manufacturing Strategies of the Large Manufacturing Companies, carried out annually since 1983 as a base for the research project entitled 'Global Manufacturing Futures Survey Project', and used by many others authors some years later (Avella et al., 1999; Boyer \& McDermott, 1999; De Meyer, 1992; Ferdows et al, 1986; Horte et al., 1991; Kim \& Arnold, 1996; Miller \& Roth, 1994; Roth \& Miller, 1990; Tunälv, 1992; Ward et al., 1988).

[Insert table 3 about here]

For each item respondents must evaluate -in a seven point scale, where one means very low, and seven very high- their relative financial investment effort. 


\subsection{Analysis of data}

In reference to the content validity of measures, the process of elaborating and refining the questionnaire mentioned above ensures it. Moreover, the set of items representing each decision in operations was obtained after reviewing the theoretical and empirical antecedents in the specialised literature. The construct validity was evaluated from a convergent point of view, since we have used multi-dimensional scales to obtain a measure of each structural and infrastructural decision. Thus, we calculated the correlation between each item, achieving very high and significant mean correlations at a confidence level of $99 \%$. The exploratory factor analysis confirmed the unidimensionality of the scales, with the 34 items being represented in seven decisions, high factor loadings and high percentage of variance explained (59.8\%).

Secondly, in order to determine the internal consistency of the measuring instrument used, we conducted a reliability analysis by the Cronbach alpha coefficient. The values obtained were superior to 0.7 in almost all cases, which means that we can be confident about the scales employed to measure each of the structural and infrastructural decisions.

Thirdly, we needed to test the representativeness of the firms for which we had information, 'i.e.' those that filled in the questionnaire correctly (353) out of the total sample (1820). This would decide if the results obtained would be generalisable (with caution) to all the organisations from the target population.

For this purpose, we analysed the proportion of firms in each main activity for both the total number of firms making up the initial sample and for the firms correctly completing the questionnaire (Table 4). We can see that the proportion and importance of each industry is maintained, since the percentages corresponding to the groupings by 


\subsection{Results}

In order to establish main operations decisions taken by Spanish manufacturing firms were obtained mean and standard deviation descriptive statistics (Table 6).

\section{[Insert table 6 about here]}

Some interesting conclusions can be obtained from a detailed analysis of these preliminary results. From the structural point of view, size and plant capacity are the 
most important variables for the studied firms; in addition, those decisions dealing with process, technology and environment protection are relevant too. Alternatively, from the infrastructural point of view, the most important manufacturing decisions are those related to quality management practices, work force, and manufacturing planning and control systems.

Additionally, it was undertaken a factorial analysis, in order to test if individual decisions can be grouped around some representative factors, and, then, to analyse their relative relevance derived from their factorial charges $\left(\lambda_{\mathrm{i}}\right)$; results are presented in Table 7.

\section{[Insert table 7 about here]}

Seven factors were identified, explaining the $59.8 \%$ of the total variance. The factorial analysis confirmed the adequate election of the items previously selected to elaborate the most representative manufacturing constructs. For the analysed firms, and in this order, work force and organisation, quality, plant capacity, operations planning, process, environmental management systems, and vertical integration were the most important decisions with respect to operations or manufacturing systems. These results show the greater relevance of short-term infrastructural decisions than those dealing with structural elements, characterized by higher financial efforts and their irreversible character. To some extent, an additional analysis of those competitive priorities defined by these companies should indicate that a notable congruence among them and the adopted operations decisions must exist (Díaz-Garrido, 2003).

To analyse the effect of these operations decisions in firm competitiveness, we developed a regression analysis where dependent variable were firm productivity and 
factors previously identified were the independent ones. The results can be seen in Table 8.

[Insert table 8 about here]

In the analysis carried out, the assumptions of normality of the distribution of the error terms, as well as the normality of the individual variables, are fulfilled.

The coefficient of determination is $26.5 \%$. From the empirical results observed, we can infer that only three independent variables -operations decisions factors- have significant effect on firm productivity: work force and organisation, process technology and environment protection. The existence of many other non-operations variables influencing the relationship between operations decisions or manufacturing capabilities and firm performance may explain these results, that other studies had previously obtained too (Boyer y McDermott, 1999; Díaz-Garrido 2003; Heineke, 1995; Kim \& Arnold, 1996; Mills et al., 1995; Safizadeh et al., 2000; Smith \& Reece, 1999).

We can conclude the relative importance of some aspects dealing with human resource management. Some researchers have previously highlighted the importance of some infrastructural elements related to work force development practices in Spanish industrial firms (Avella et al., 1999). Then, although companies have focused their attention on structural decisions, nowadays the importance of infrastructural decisions is recognised too. Hence, for example, a large number of companies have been capable of developing a powerful competitive advantage based on their employees' abilities, even without having exceptional plants and equipments (see Avella et al., 1999; Hayes \& Wheelwright, 1988).

In short, our results suggest that work force development practices are directly related to firm productivity. Moreover, our results indicate that practices with regards to process 
technology and environment protection are likely to be important drivers to improve

performance in today's manufacturing environment too.

\section{Conclusions and future research}

Several elements controlled by firms can notably influence their competitiveness. In this paper, we paid special attention to those related to manufacturing decisions. From previous proposals, we can infer that operations strategy can contribute to better results. To create wealth from the operations area, it is necessary to define properly the most relevant operations competitive priorities and implement some value-creating operations strategies, practices or decisions. In short, both competitive priorities and operations decisions establish the content of the operations strategy.

Although literature has traditionally analysed the relationship between competitive priorities and competitive strategies, operations strategies, at functional level has been isolated. Because of that, our research agenda is focused on those decisions that must be included in the operations strategy and their effect on firm competitiveness, in terms of its productivity.

Previous literature review let us elaborate a theoretical framework for the analysis of manufacturing decisions. Taking into account the extant research, we can distinguish between structural (plant capacity and localization, production process technology, and vertical integration) and infrastructural (quality control and work force, operations planning and control and organisation) manufacturing decisions. Furthermore, nowadays we can add one relevant question: environmental management systems.

In this paper we have tried to offer some empirical evidence on the current situation of industrial firms with regards the development of operations decisions that allow firms to 
achieve sustainable competitive advantages. From a sample of 353 manufacturing Spanish firms, we, firstly, have analysed the relative importance of operations decisions to the Spanish manufacturing firms studied here. Following mean scores, we can conclude that some structural and infrastructural decisions are complementary and relevant; the most important ones are plant capacity, quality control systems, work force and operations planning.

Secondly, the factorial analysis developed here showed the properly definition of the items included in the survey concerning manufacturing decisions. Summing up, seven factors or operations decision areas were identified; work force and organisation, quality, plant capacity, operations planning, process, environmental management systems, and vertical integration were the most important decisions with respect to operations or manufacturing systems. These findings are important not only to better understand our theoretical knowledge dealing with manufacturing decisions, but also because they have practical implications for operations managers.

To analyse the relationship between operations efforts area and firm competitiveness, was conducted a lineal regression analysis. The dependent variable was firm productivity and the independent variables were each operations decisions area previously identified. From this analysis, we can conclude that only work force and organisation, process technology and environment protection significantly influence firm performance; nevertheless, the model had only a significance of $26 \%$. Although some new variables should be included in the model, the empirical results obtained here must be positively considered, taking into account previous empirical studies (see Vickery, 1991; Kim \& Arnold, 1992). 
For managers, these findings highlight the importance of infrastructural decisions, and suggest the existence of some critical ones.

However, these results may imply a challenging question: Are manufacturing decisions of no relevance? We consider that firm competitiveness depends on other additional variables that should be included in future research. In short, it is very difficult to measure the individual influence of operations decisions and to analyse their effects in isolation.

In this sense, firms are expected to develop the appropriate changes to achieve better results. From this point of view, we think that future research must be oriented to surpass these shortcomings in order to reach a greater understanding about the role of operations strategies in firm success.

\section{References}

Acur, N., Gertsen, F., Sun, H. and Frick, J. The formalisation of manufacturing strategy and its influence on the relationship between competitive objectives, improvement goals, and action plans. International J Operations and Production Mangement, 2003, 23 (10), 1114-1141.

Anderson, J.C., Schroeder, R.G. and Cleveland, G., Operations strategy: a literature review. J Operations Management,1989, 8 (2),1-26.

Avella, L., Fernández, E. And Vazquez, C.J., The large Spanish industrial company: strategies of the most competitive factories. Omega, 1999, 27, 497-514.

Boyer, K. K., Longitudinal linkages between intended and realized operations strategies. International J Operations and Production Management, 1998, 18 (4), 356373.

Boyer, K.K. and McDermott, C., Strategic consensus in operations strategy. $J$ Operations Management, 1999, 17 (2), 289-305.

Boyer, K.K., Ward, P. T. and Leong, C.K., Approaches to the factory of the future. An empirical taxonomy. J. Operations Management, 1996, 14 (3), 297-313.

Bradford, C., The New Paradigm of Systemic Competitiveness: Toward more Integrated Policies in Latin America, 1994 (OCDE: Paris).

Buffa, E., Meeting the Competitive Challenge, 1984 (Down Jones-Irwin. Homewood, IL). 
Christiansen, T., Berry, W.L., Bruun, P. and Ward, P., A mapping of competitive priorities, manufacturing practices, and operational performance in groups of Danish manufacturing companies. International J. Operations and Production Management, 2003, 23(10), 1163-1183.

Cleveland, G., Schroeder, R.G. and Anderson, J.C., A theory of production competence. Decision Science, 1989, 20 (4), 655-668.

Cohen, M.A. and Lee, H.L., Manufacturing strategy: concepts and methods. In The Management of Productivity and Technology in Manufacturing, edited by R.K. Paul, pp. 35-49, 1985 (Plenum Press: New York).

\section{Corbett, C., Van Wassenhove, L., Trade-offs? What trade-offs? Competence and Competitiveness in Manufacturing Strategy". California Management Review, 1993, 36 (summer), 107-122.}

De Meyer, A., An empirical investigation of manufacturing strategies in European industry. In Manufacturing Strategy, Process and Content, edited by C.A. Voss, pp.221-238, 1992 (Chapman \& Hall: London).

Díaz-Garrido, E., La estrategia funcional de producción: una propuesta de configuraciones genéricas en la industria española. PhD thesis, Rey Juan Carlos University, 2003.

Ferdows, K.; Miller, J.G.; Nakane, J. and Vollmann, T., Evolving global manufacturing strategies: projection into the 1990's. International J. Operations and Production Management, 1986, 6 (4), 6-16.

Fine. C.H. and Hax. A.C., Manufacturing strategy: a methodology and an illustration. Interfaces, 1985, 15 (6), 28-46.

Giffi, C.; Roth A.V. and Seal, G., Competing in World Class Manufacturing America's $21^{\text {st }}$ Century Challenge, 1990 (Business One Irwin: Homewood, IL).

Gupta, M.C., Environmental management and its impact on the operations function. International J. Operations and Production Management, 1995, 15 (8), 34-51.

Hayes, R.H. and Abernathy, W.J. Managing our way to economic decline. Harvard Business Review, 1980, 58 (july-august), 67-77.

Hayes, R.H. and Schmenner, R.W., How should organize manufacturing?. Harvard Business Review, 1978, 56 (January-February), 105-119.

Hayes, R.H. and Wheelwright, S.C., Restoring Our Competitive Edge: Competing through Manufacturing, 1984 (John Wiley: New York).

Hayes, R.H., Wheelwright, S.C. and Clark, K.B., Dynamic Manufacturing, 1988 (The Free Press: New York).

Heineke, J., Strategic operations management decisions and professional performance in U.S. HMOS. J. of Operations Management, 1995, 13 (3), 255-272.

\section{Hill, T. J., Manufacturing Strategy. Text and Cases, 1989 (Irwin: Homewood, IL).}

Hill, T.J., Manufacturing Strategy. The Strategic Management of the Manufacturing Function, 1993 (Macmillan: London). 
Hörte, S.A.; Börjesson, S. and Tunälv, C., A panel study of manufacturing strategy in Sweden. International J. Operations and Production Management, 1991, 11 (3), 135144.

Kathuria, R., Competitive priorities and managerial performance: a taxonomy of small manufacturers. J of Operations Management, 2000, 18 (6), 627-641.

Kim, J.S. and Arnold, P., Manufacturing competence and business performance: a framework and empirical analysis. International $J$ of Operations and Production Management, 1992, 13 (10), 4-25.

Kim, J.S. and Arnold, P. Operationalizing manufacturing strategy: an exploratory study of construct and linkage. International J. of Operations and Production Management, 1996, 16 (12), 45-73.

Krajewsky, L.J. and Ritzman, L.P., Operations Management. Strategy and Analysis, 2000 (Adisson Wesley).

Leong, G., Snyder, D. and Ward, P., Research in the process and content of manufacturing strategy. Omega, 1990, 18 (2), 109-122.

Marucheck, A., Parnnesi, R. and Anderson, C., An exploratory study of the manufacturing strategy process in practice. J. Operations Management, 1990, 9 (1), 101-123.

Meredith, J., The strategic advantages of new manufacturing technologies for small firms. Strategic Management Journal, 1987, 8 (3), 249-258.

Miller, J.G., De Meyer, A., Nakane, J., Benchmarking Global Manufacturing. Understanding International Suppliers, Customers and Competitors, 1992 (Irwin: USA).

Miller, J.G. and Roth, A.V., A taxonomy of manufacturing strategies. Management Science, 1994, 40 (3), 285-304.

Mills, J., Platts, K. and Gregory, M., A framework for the design of manufacturing strategy processes: a contingency approach. International J. Operations and Production Management, 1995, 15 (4), 17-49.

Narasimhan, R., Swink, M. and Kim, S.W., An exploratory study of manufacturing practice and performance interrelationships. Implications for capability progression. International J. Operations and Production Management, 2005, 25 (10), 1013-1033.

Noble, M. A., Manufacturing Strategy: Testing the Cumulative Model in a Multiple Country Context. Decision Sciences, 1995, 26 (5), 693-721.

Platts, K.W. and Gregory, M.J., Manufacturing audit in the process of strategy formulation. International J. of Operations and Production Management, 1990, 10 (9), $5-26$.

Platts, K.W. and Gregory, M.J., A manufacturing audit approach to strategy formulation. In Manufacturing Strategy, Process and Content, edited by C.A. Voss, pp. 29-55, 1992 (Chapman \& Hall: London).

Prahalad, C.K. and Hamel, G., The core competence of the corporation. Harvard Business Review, 1990, 68, 79-91. 
Roth, A.V., Linking manufacturing strategy and performance: an empirical investigation. Working Paper No. 617/353-4282, Boston University, School of Management, USA, 1989.

Roth, A.V. and Miller, J.G., Manufacturing strategy, manufacturing strength, managerial success and economic outcomes. In Manufacturing Strategy: The Research Agenda for the Next Decade, edited by J.E. Ettlie, M.C. Burstein and A. Fiegenbaum, pp. 97-108, 1990 (Kluwer Academic Publisher: Boston).

Safizadeh, M.H.; Ritzman, L.P. and Mallick, D., Revisting alternative theoretical paradigms in manufacturing strategy. Production and Operations Management, 2000, 9 (2), 111-127.

Schonberger, R.J., World Class Manufacturing, 1986 (Free Press: New York).

Schonberger, R.J. and Knod, E.M., Operations Management, Serving the Customer, 1988 (TX Business Publications).

Schroeder, R.G., Operations Management, 1981 (McGraw-Hill: New York).

Schroeder, R.G., Anderson, J.C. and Cleveland, G., The content of manufacturing strategy: an empirical study. J Operations Management, 1986, 6 (4), 405-416.

\title{
Shrivastava, P., Environmental technologies and competitive advantage, Strategic Management J., 1995, 16, 77-91.
}

Skinner, W., Manufacturing missing link in corporate strategy. Harvard Business Review, 1969, 47 (July-August), 136-145.

Skinner, W., Manufacturing. The Formidable Competitive Weapon, 1985 (John Wiley: USA).

Slack, N. and Lewis, M.A. Operations Strategy, 2002 (Prentice-Hall: London).

Smith, T.S. and Reece, J.S., The relationship of strategy, fit, productivity, and business performance. J. of Operations Management, 1999, 17 (2), 147-161.

Stobaugh, R. and Telesio, P., Match manufacturing policies and product strategy. Harvard Business Review, 1983, 62 (March-April), 113-120.

Swamidass, P.M., Manufacturing strategy: its assessment and practice. J. Operations Management, 1986, 6 (4), 471-484.

Swamidass, P.M. and Newell, W.T., Manufacturing strategy, environmental uncertainty and performance: a path analytical model. Management Science, 1987, 33 (4), 509-524.

\begin{abstract}
Swink, M., Narasimhan, R. and Kim S.W., Manufacturing practices and strategy integration: effects on cost efficiency, flexibility, and market-based performance. Decision Sciences, 2005, 36 (3), 427-435.
\end{abstract}

Teece, D. and Pisano, G., The dynamic capabilities of firms: an introduction. Industrial and Corporate Change, 1994, 3 (3), 537-556.

Tunälv, C., Manufacturing strategy plans and business performance. International J. Operations and Production Management, 1992, 12 (3), 4-24.

Vickery, S. K., A theory of production competence revisted, Decision Sciences, 1991, $22(3), 635-643$. 
Voss, C.A., Alternative paradigms for manufacturing strategy. International $J$. Operations \& Production Management, 1995, 15(4), 5-16.

Ward, P., Miller, J.G. and Vollman, T., Mapping manufacturers concerns and action plans. International J. Operations and Production Management, 1988, 8 (6), 5-17.

Ward, P.; Leong, G.K.; Boyer, K.K., Manufacturing proactiveness and performance. Decision Sciences, 1994, 25 (3), 337-358

Wheelwright, S.C., Reflecting corporate strategy in manufacturing decisions. Business Horizons, 1978, February, 57-66.

Wheelwright, S.C., Japan-Where Operations Really are Strategic. Harvard Business Review, 1981, 59 (July-August), 67-74.

Wheelwright, S. C., Manufacturing strategy: defining the missing link. Strategic Management J., 1984, 5 (1), 77-91.

Wheelwright, S.C. and Hayes, R.H., Competing through manufacturing. Harvard Business Review, 1985, 63 (January-February), 99-109. 
Table Caption

Table 1. Manufacturing decisions or practices

\begin{tabular}{|c|c|c|}
\hline REFERENCES & STRUCTURAL DECISIONS & INFRASTRUCTURAL DECISIONS \\
\hline Skinner (1969) & - Layout and equipment & $\begin{array}{ll}\text { - } & \text { Control and planning } \\
\text { - } & \text { Organisation design and management } \\
\text { - } & \text { Human resources } \\
\text { Product design }\end{array}$ \\
\hline Wheelwright (1981) & $\begin{array}{ll} & \text { Product and process technology } \\
\text { - } & \text { Vertical integration } \\
\text { - } & \text { Capacity } \\
\end{array}$ & $\begin{array}{ll}\text { - } & \text { Operations and material planning } \\
\text { - } & \text { Organisational design } \\
\text { - } & \text { Quality control } \\
\end{array}$ \\
\hline $\begin{array}{l}\text { Wheelwright (1978) } \\
\text { Hayes \& } \\
\text { Wheelwright (1984) } \\
\text { Hayes, Wheelwright, } \\
\text { and Clark (1996) }\end{array}$ & $\begin{array}{l}\text { - } \quad \text { Process technology } \\
\text { - } \quad \text { Vertical integration } \\
\text { - } \quad \text { Facilities (size and localization) }\end{array}$ & $\begin{array}{ll}\text { - } & \text { Operations planning and control systems } \\
\text { - } & \text { Human resources management } \\
\text { - } & \text { Quality management } \\
\text { - } & \text { Systems fopment of new products } \\
& \text { performance }\end{array}$ \\
\hline Buffa (1984) & $\begin{array}{l}\text { - } \quad \text { Process and product technology } \\
\text { - } \quad \text { Suppliers strategy } \\
\text { - } \quad \text { apacity and localization }\end{array}$ & $\begin{array}{ll}\text { - } & \text { Strategic implications of operations } \\
\text { decisions } \\
\text { - } & \text { Work design and work force } \\
\text { - } & \text { Operations systems }\end{array}$ \\
\hline Fine \& Hax (1985) & $\begin{array}{ll}\text { - } & \text { Process technology } \\
\text { - } & \text { Vertical integration } \\
\text { - } & \text { Capacity } \\
\end{array}$ & $\begin{array}{ll}\text { - } & \text { Control Systems } \\
\text { - } & \text { Human resources } \\
\text { - } & \text { Quality } \\
\end{array}$ \\
\hline $\begin{array}{l}\text { Schonberger \& Knod } \\
\text { (1988) }\end{array}$ & Not included & $\begin{array}{ll}- & \text { Operations planning } \\
\text { - } & \text { Operations programming } \\
\text { - } & \text { Inventory control } \\
\text { Maintenance }\end{array}$ \\
\hline $\begin{array}{l}\text { Platts \& Gregory } \\
(1990,1992)\end{array}$ & $\begin{array}{ll}\text { - } & \text { Manufacturing process } \\
\text { - } & \text { Suppliers } \\
\text { - } & \text { Capilities } \\
\end{array}$ & $\begin{array}{ll}\text { - } & \text { Control systems } \\
\text { - } & \text { Quality } \\
\text { - } & \text { Human resources } \\
& \text { New products }\end{array}$ \\
\hline $\begin{array}{l}\text { Krajewsky \& } \\
\text { Ritzman (2000) }\end{array}$ & $\begin{array}{ll}\text { - } & \text { Technological innovation } \\
\text { - } & \text { Product and process selection } \\
& \text { Long run objectives definition } \\
\end{array}$ & $\begin{array}{ll}\text { - } & \text { Work force } \\
\text { - } & \text { Quality management } \\
\text { - } & \text { Process and product design }\end{array}$ \\
\hline
\end{tabular}

Table 2. Literatura Review: Manufacturing Decisions

\begin{tabular}{|c|c|c|c|}
\hline \multirow{6}{*}{$\begin{array}{l}\text { Structural } \\
\text { Decisions }\end{array}$} & \multirow{3}{*}{ Technology } & Technology process & Schroeder et al. (1986) \\
\hline & & $\begin{array}{l}\text { Advanced Manufacturing } \\
\text { Technology investments (design } \\
\text { and production) }\end{array}$ & $\begin{array}{l}\text { Ferdows et al. (1986), Ward et al. (1988), Roth } \\
\text { and Miller (1990), Horte } \text { et al. (1991), De Meyer } \\
\text { (1992), Miller et al. (1992), Tunälv (1992), Ward } \\
\text { et al. (1994), Kim and Arnold (1996), Boyer } \\
\text { (1998), Avella et al. (1999), Boyer and } \\
\text { McDermott (1999), Narasimhan } \text { et al. (2005), } \\
\text { Swink et al. (2005) }\end{array}$ \\
\hline & & $\begin{array}{l}\text { AMT investments } \\
\text { (administrative) }\end{array}$ & $\begin{array}{l}\text { Boyer (1998), Boyer and McDermott (1999), } \\
\text { Narasimhan et al. (2005), Swink et al. (2005) }\end{array}$ \\
\hline & \multirow[t]{3}{*}{ Installations } & Focus of facilities & Schroeder et al. (1986) \\
\hline & & Reconditioning of physical plant & $\begin{array}{l}\text { Ferdows et al. (1986), De Meyer (1992), Miller et } \\
\text { al. (1992), Avella et al. (1999) }\end{array}$ \\
\hline & & Plant location and re-location & $\begin{array}{l}\text { Ferdows et al. (1986), Ward et al. (1988), } \\
\text { Schroeder } \text { et al. (1986), De Meyer (1992), Miller } \\
\text { et al. (1992), Kim and Arnold (1996), Avella et } \\
\text { al. (1999) }\end{array}$ \\
\hline
\end{tabular}


Infrastructural decisions

\begin{tabular}{|l|l|}
\hline \multirow{4}{*}{$\begin{array}{c}\text { Vertical } \\
\text { integration }\end{array}$} & Plant capacity \\
\cline { 2 - 2 } & $\begin{array}{l}\text { Cooperation with suppliers } \\
\text { Integrating information systems } \\
\text { with suppliers }\end{array}$ \\
\cline { 2 - 2 } & \\
\hline
\end{tabular}

Ward et al. (1988), Roth and Miller (1990), Horte et al. (1991), De Meyer (1992), Tunälv (1992), Avella et al. (1999)

Ferdows et al. (1986), Schroeder et al. (1986), Avella et al. (1999), Narasimhan et al. (2005), Swink et al. (2005) Avella et al. (1999) Ferdows et al. (1986), Ward et al. (1988), Roth and Miller (1990), De Meyer (1992), Miller et al. (1992), Kim Arnold (1996), Avella et al. (1999), Narasimhan et al. (2005), Swink et al. (2005)

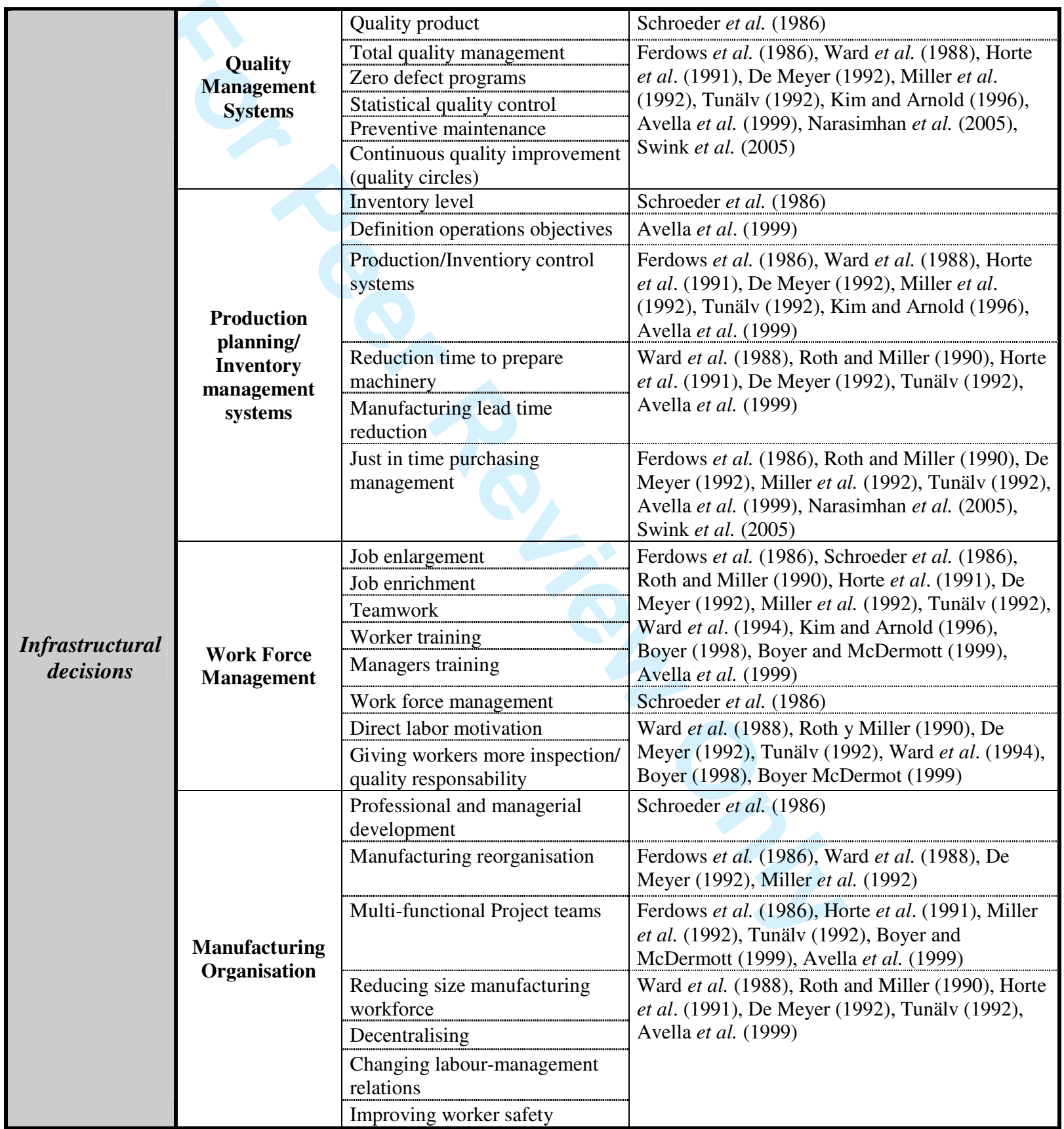




\begin{tabular}{|c|c|c|c|}
\hline \multicolumn{4}{|c|}{ Table 3. Measures of variables } \\
\hline \multicolumn{2}{|r|}{ STRUCTURAL DECISIONS } & \multicolumn{2}{|c|}{\begin{tabular}{|c|} 
INFRASTRUCTURAL DECISIONS \\
\end{tabular}} \\
\hline $\begin{array}{l}\text { Plant } \\
\text { Capacity }\end{array}$ & $\begin{array}{l}\text { - } \quad \text { Re-configuration of plant layout } \\
\text { - } \quad \text { Reconditioning of physical plant } \\
\text { - } \text { Investment in plant, equipment } \\
\text { and R+D } \\
\text { - } \quad \text { Capacity expansion }\end{array}$ & $\begin{array}{l}\text { Work Force } \\
\text { Management }\end{array}$ & $\begin{array}{l}\text { - } \quad \begin{array}{l}\text { Giving workers a broad rage of task } \\
\text { - }\end{array} \text { Givb enlargement) } \\
\text { responsibility (job enrichment) } \\
\text { - } \quad \text { Teamwork } \\
\text { - Worker training }\end{array}$ \\
\hline Localization & - $\quad$ Plant location and re-location & & - $\quad$ Management training \\
\hline $\begin{array}{l}\text { Process } \\
\text { Technology }\end{array}$ & $\begin{array}{l}\text { - } \text { Computer aided Design (CAD) } \\
\text { (CAM) } \\
\text { - } \text { Robots } \\
\text { - Flexible Manufacturing Systems }\end{array}$ & $\begin{array}{l}\text { Quality } \\
\text { Management }\end{array}$ & $\begin{array}{ll}\text { - } & \text { Total Quality Management (TQM) } \\
\text { - } & \text { Zero defect programs } \\
\text { - } & \text { Statistical quality control } \\
\text { - } & \text { Preventive maintenance } \\
\text { - } & \text { Continuous quality improvement } \\
\text { - } & \text { ISO } 9000\end{array}$ \\
\hline $\begin{array}{l}\text { Vertical } \\
\text { Integration }\end{array}$ & $\begin{array}{ll}\text { - } & \text { Sub-contracting } \\
\text { - } & \text { Cooperation with suppliers } \\
& \text { Integrating information systems } \\
& \text { with suppliers }\end{array}$ & $\begin{array}{l}\text { Production } \\
\text { Planning/Inventory } \\
\text { Management } \\
\text { Systems }\end{array}$ & $\begin{array}{ll}\text { - } & \text { Production/Inventory control systems } \\
\text { - } & \text { Reduction of time required to prepare } \\
\text { - } & \text { machinery } \\
\text { - } & \text { Junufacturing lead time reduction } \\
\end{array}$ \\
\hline $\begin{array}{l}\text { Environm. } \\
\text { Protection } \\
\text { Programs }\end{array}$ & $\begin{array}{ll}\text { - } & \text { Environmental Management } \\
\text { - } & \text { Systems } \\
\text { ISO } 14001\end{array}$ & $\begin{array}{l}\text { Manufacturing } \\
\text { Organisation }\end{array}$ & $\begin{array}{ll}\text { - } & \text { Decentralising } \\
\text { - } & \text { Improving relations between } \\
\text { - } & \text { management and workers } \\
\text { - } & \text { Multi-functional project teams }\end{array}$ \\
\hline
\end{tabular}

\begin{tabular}{|c|c|c|c|c|c|}
\hline CNAE & DESCRIPTION OF ACTIVITY & $\begin{array}{l}\mathrm{N}^{\circ} \\
\text { FIRMS }\end{array}$ & $\begin{array}{c}\% \\
\text { TOTAL } \\
\text { SAMPLE } \\
\end{array}$ & $\begin{array}{l}\mathrm{N}^{\circ} . \\
\text { RESPONSES }\end{array}$ & $\begin{array}{c}\% \\
\text { RESPONSES }\end{array}$ \\
\hline 27 & Metallurgy & 193 & 10.60 & 36 & 10.19 \\
\hline 28 & $\begin{array}{l}\text { Manufacture of metallic products, except machinery } \\
\text { and equipment }\end{array}$ & 575 & 31.59 & 106 & 30.07 \\
\hline 29 & $\begin{array}{l}\text { Manufacture of machinery and mechanical } \\
\text { equipment }\end{array}$ & 440 & 24.18 & 81 & 22.94 \\
\hline 30 & $\begin{array}{l}\text { Manufacture of office machines and computing } \\
\text { equipment }\end{array}$ & 17 & 0.93 & 6 & 1.69 \\
\hline 31 & Manufacture of electrical machinery and material & 245 & 13.46 & 47 & 13.31 \\
\hline 32 & $\begin{array}{l}\text { Manufacture of electronic material, radio, TV and } \\
\text { communications equipment and receivers }\end{array}$ & 85 & 4.67 & 14 & 3.96 \\
\hline 33 & $\begin{array}{l}\text { Manufacture of medical-surgical and precision } \\
\text { equipment and instruments, optical instruments and } \\
\text { clocks }\end{array}$ & 65 & 3.57 & 11 & 3.11 \\
\hline 34 & $\begin{array}{l}\text { Manufacture of motor vehicles, trailers and semi- } \\
\text { trailers }\end{array}$ & 200 & 11.00 & 52 & 14.73 \\
\hline \multicolumn{2}{|r|}{ TOTAL } & 1820 & 100 & 353 & 100 \\
\hline
\end{tabular}

Table 5. Analysis of systematic bias in terms of industry

\begin{tabular}{|c|c|c|c|c|c|c|}
\hline \multirow{2}{*}{$\begin{array}{c}\text { Mean whole } \\
\text { sample }\end{array}$} & \multirow{2}{*}{$\begin{array}{l}\text { Mean study } \\
\text { firms }\end{array}$} & \multirow{2}{*}{$\begin{array}{c}\text { Difference of } \\
\text { means }\end{array}$} & \multicolumn{2}{|c|}{ Confidence interval } & \multirow{2}{*}{$\mathrm{t}$} & \multirow{2}{*}{ Sig. } \\
\hline & & & Lower & Higher & & \\
\hline 12.5 & 11.3 & 0.092 & -1.3862 & 0.5795 & 0.120 & 0.951 \\
\hline
\end{tabular}


Table 6. Descriptive analysis for manufacturing decisions

\begin{tabular}{|c|c|c|c|c|c|}
\hline STRUCTURAL DECISIONS & Mean & $\begin{array}{l}\text { Stand. } \\
\text { Desv. }\end{array}$ & $\begin{array}{l}\text { INFRASTRUCTURAL } \\
\text { DECISIONS }\end{array}$ & Mean & $\begin{array}{l}\text { Stand. } \\
\text { Desv. }\end{array}$ \\
\hline Re-configuration of plant layout & 5.07 & 1.25 & Job enlargement & 4.78 & 1.42 \\
\hline Reconditioning of physical plant & 5.26 & 1.20 & Job enrichment & 5.06 & 1.34 \\
\hline Investment in plant., equipment and $\mathrm{R}+\mathrm{D}$ & 5.46 & 1.24 & Teamwork & 5.40 & 1.31 \\
\hline Capacity expansion & 5.28 & 1.33 & Worker training & 5.70 & 1.06 \\
\hline Plant location and re-location & 3.23 & 1.85 & Management training & 5.52 & 1.24 \\
\hline $\begin{array}{l}\text { Computer aided Design (CAD) } \\
\text { Computer aided Manufacturing (CAM) } \\
\text { Robots } \\
\text { Flexible Manufacturing Systems }\end{array}$ & $\begin{array}{l}5.01 \\
4.05 \\
3.71 \\
5.15\end{array}$ & $\begin{array}{l}1.63 \\
1.80 \\
1.91 \\
1.76\end{array}$ & $\begin{array}{l}\text { Total Quality Management (TQM) } \\
\text { Zero defect programs } \\
\text { Quality circles } \\
\text { Statistical quality control } \\
\text { Preventive maintenance } \\
\text { Continuous quality improvement } \\
\text { ISO } 9000\end{array}$ & $\begin{array}{l}5.61 \\
4.90 \\
4.76 \\
5.19 \\
5.25 \\
5.69 \\
5.74\end{array}$ & $\begin{array}{l}1.23 \\
1.59 \\
1.49 \\
1.32 \\
1.32 \\
1.09 \\
1.19\end{array}$ \\
\hline $\begin{array}{l}\text { Sub-contracting } \\
\text { Cooperation with suppliers } \\
\text { Integrating information systems suppliers }\end{array}$ & $\begin{array}{l}4.48 \\
5.09 \\
4.04\end{array}$ & $\begin{array}{l}1.66 \\
1.36 \\
1.53\end{array}$ & $\begin{array}{l}\text { Production/Inventory control systems } \\
\text { Reduction time to prepare machinery } \\
\text { Manufacturing lead time reduction } \\
\text { Just-in-time purchasing management }\end{array}$ & $\begin{array}{l}5.36 \\
4.94 \\
5.53 \\
4.81\end{array}$ & $\begin{array}{l}1.17 \\
1.59 \\
1.25 \\
1.54\end{array}$ \\
\hline $\begin{array}{l}\text { Environmental Management Systems } \\
\text { ISO } 14001\end{array}$ & $\begin{array}{l}4.99 \\
4.89\end{array}$ & $\begin{array}{l}1.47 \\
1.52\end{array}$ & $\begin{array}{l}\text { Improving relations managers- } \\
\text { workers } \\
\text { Improving worker safety } \\
\text { Multi-functional project teams }\end{array}$ & $\begin{array}{l}4.45 \\
5.10 \\
5.31 \\
4.62\end{array}$ & $\begin{array}{l}1.45 \\
1.47 \\
1.25 \\
1.46\end{array}$ \\
\hline
\end{tabular}

\begin{tabular}{|c|c|c|c|c|c|c|c|c|}
\hline \multicolumn{9}{|c|}{ Table 7. Rotated components matrix } \\
\hline Items & 1 & 2 & 3 & 4 & 5 & 6 & 7 & Factors \\
\hline Job enrichment & 0.759 & 0.124 & 0.309 & 0.010 & -0.001 & 0.008 & 0.185 & \multirow{9}{*}{$\begin{array}{c}\text { Factor } 1 \\
\text { Workforce } \\
\text { and } \\
\text { Organisation }\end{array}$} \\
\hline Teamwork & 0.727 & 0.187 & 0.245 & -0.016 & 0.069 & 0.006 & 0.121 & \\
\hline Improving relations management workers & 0.695 & 0.062 & -0.027 & 0.186 & 0.159 & 0.088 & 0.031 & \\
\hline Decentralising & 0.663 & 0.102 & -0.069 & 0.152 & 0.123 & 0.090 & 0.077 & \\
\hline Job enlargement & 0.633 & 0.039 & 0.237 & 0.195 & 0.029 & 0.185 & 0.165 & \\
\hline Worker training & 0.563 & 0.421 & 0.151 & 0.221 & 0.029 & 0.003 & 0.164 & \\
\hline Improving worker safety & 0.509 & 0.352 & 0.147 & 0.125 & 0.019 & 0.239 & 0.011 & \\
\hline Multi-functional project teams & 0.503 & 0.115 & 0.106 & 0.095 & 0.138 & 0.457 & 0.027 & \\
\hline Management training & 0.399 & 0.316 & 0.066 & 0.276 & 0.073 & 0.120 & 0.217 & \\
\hline Statistical quality control & 0.078 & 0.710 & 0.131 & 0.265 & 0.092 & 0.067 & 0.137 & \multirow{6}{*}{$\begin{array}{c}\text { Factor } 2 \\
\text { Quality }\end{array}$} \\
\hline ISO 9000 & 0.138 & 0.654 & 0.083 & 0.034 & 0.010 & 0.217 & 0.227 & \\
\hline Quality circles & 0.093 & 0.647 & 0.084 & 0.125 & 0.084 & 0.154 & -0.014 & \\
\hline Total Quality Management (TQM) & 0.285 & 0.612 & 0.001 & -0.023 & 0.120 & 0.444 & 0.057 & \\
\hline Zero defect programs & 0.116 & 0.598 & 0.056 & 0.015 & 0.305 & 0.216 & 0.009 & \\
\hline Preventive maintenance & 0.278 & 0.556 & 0.100 & 0.132 & 0.253 & -0.021 & -0.022 & \\
\hline Reconditioning of physical plant & 0.190 & 0.043 & 0.810 & 0.209 & 0.120 & 0.048 & 0.039 & \multirow{4}{*}{$\begin{array}{c}\text { Factor } 3 \\
\text { Plant } \\
\text { Capacity }\end{array}$} \\
\hline Re-configuration of plant layout & 0.137 & 0.077 & 0.808 & 0.198 & 0.061 & 0.137 & 0.037 & \\
\hline Investment in plant, equipment and $\mathrm{R}+\mathrm{D}$ & 0.069 & 0.111 & 0.585 & 0.002 & 0.170 & 0.143 & 0.233 & \\
\hline Capacity expansion & 0.205 & 0.190 & 0.536 & 0.137 & 0.118 & -0.051 & -0.010 & \\
\hline Manufacturing lead $t$ & 0.214 & 0.117 & 0.188 & 0.760 & 0.145 & 0.057 & 0.041 & \multirow{4}{*}{$\begin{array}{c}\text { Factor } 4 \\
\text { Production } \\
\text { Planning }\end{array}$} \\
\hline Production/Inventory control systems & 0.138 & 0.226 & 0.248 & 0.713 & 0.175 & -0.028 & 0.164 & \\
\hline Just-in-time purchasing management & 0.181 & 0.133 & 0.059 & 0.527 & -0.077 & 0.183 & 0.272 & \\
\hline Continuous quality improvement & 0.310 & 0.419 & 0.196 & 0.514 & 0.136 & -0.061 & -0.014 & \\
\hline Computer aided Manufacturing (CAM) & 0.054 & 0.163 & 0.073 & 0.155 & 0.771 & 0.126 & 0.177 & \multirow{5}{*}{$\begin{array}{c}\text { Factor } 5 \\
\text { Process } \\
\text { Technology }\end{array}$} \\
\hline Flexible Manufacturing Systems & 0.147 & 0.168 & 0.125 & 0.021 & 0.712 & -0.049 & 0.070 & \\
\hline Robots & 0.078 & 0.104 & 0.064 & 0.166 & 0.540 & 0.196 & 0.004 & \\
\hline Computer aided Design (CAD) & -0.038 & 0.073 & 0.249 & -0.168 & 0.497 & -0.078 & 0.456 & \\
\hline $\begin{array}{l}\text { Reduction time required prepare } \\
\text { machinery }\end{array}$ & 0.375 & 0.219 & 0.151 & 0.340 & 0.438 & 0.046 & -0.103 & \\
\hline ISO 14001 & 0.064 & 0.327 & 0.040 & 0.042 & 0.012 & 0.803 & 0.087 & \multirow{2}{*}{$\begin{array}{c}\text { Factor } 6 \\
\text { Environment } \\
\end{array}$} \\
\hline Environmental Management Systems & 0.220 & 0.306 & 0.128 & 0.029 & 0.157 & 0.750 & 0.032 & \\
\hline Sub-contracting & 0.106 & 0.008 & 0.043 & 0.050 & 0.096 & 0.013 & 0.780 & Factor 7 \\
\hline
\end{tabular}




\section{Cooperation with suppliers}

Integrating information systems suppliers

Plant location and re-location

0.262

0.203

0.003

0.201

0.132

0.070

0.023

0.249

0.130

0.051

0.133

0.018

0.180

$-0.033$

$0.080 \quad-0.205$

0.645

0.589

0.207

Vertical Integration Extraction method: principal components analysis. Rotation method: Kaiser Varimax Normalization.

\begin{tabular}{|l|r|r|r|r|r|r|}
\hline \multicolumn{7}{|c|}{ Table 8. Regression analysis: empirical results } \\
\cline { 2 - 6 } & \multicolumn{2}{|c|}{$\begin{array}{c}\text { Non-standardized } \\
\text { Coefficients }\end{array}$} & $\begin{array}{c}\text { Standardized } \\
\text { Coefficients }\end{array}$ & \multirow{2}{*}{ t } & \multirow{2}{*}{ Sig. } & FIV \\
\cline { 2 - 7 } & \multicolumn{1}{|c|}{ B } & Typ. error & Beta & & & \\
\hline (Constant) & 169.4 & 9.091 & & 18.64 & .000 & \\
\hline Factor 1: Workforce and Organisation & 11.62 & 9.104 & .067 & 1.547 & $.100^{* *}$ & 1.000 \\
Factor 2: Quality & 1.928 & 9.104 & .011 & .212 & .832 & 1.000 \\
Factor 3: Plant capacity & -2.407 & 9.104 & -.014 & -.264 & .792 & 1.000 \\
Factor 4: Production Planning & 8.945 & 9.104 & .051 & .983 & .327 & 1.000 \\
Factor 5: Process Technology & 20.45 & 9.104 & .117 & 2.247 & $.025^{*}$ & 1.000 \\
Factor 6: Environment Protection & 26.36 & 9.104 & .151 & 2.896 & $.004^{*}$ & 1.000 \\
Factor 7: Vertical Integration & -12.66 & 9.104 & -.073 & -1.391 & .165 & 1.000 \\
\hline
\end{tabular}

$$
\begin{aligned}
& * \mathrm{p}<0.05 \\
& * * \mathrm{p}<0.10
\end{aligned}
$$

